\title{
Apoptosis-inducing Effect of Hydroquinone 5-O-Cinnamoyl Ester Analog of Renieramycin M on Non-small Cell Lung Cancer Cells
}

\author{
ARNATCHAI MAIUTHED ${ }^{1,2}$, TATCHAKORN PINKHIEN ${ }^{2}$, \\ SUPAKARN CHAMNI $^{3}$, KHANIT SUWANBORIRUX ${ }^{3}$, NAOKI SAITO ${ }^{4}$, \\ NAREERAT PETPIROON ${ }^{2}$ and PITHI CHANVORACHOTE ${ }^{1,2}$ \\ Departments of ${ }^{1}$ Pharmacology and Physiology, and ${ }^{3}$ Pharmacognosy and Pharmaceutical Botany, \\ Faculty of Pharmaceutical Sciences, Chulalongkorn University, Bangkok, Thailand; \\ ${ }^{2}$ Cell-Based Drug and Health Product Development Research Unit, Chulalongkorn University, Bangkok, Thailand; \\ ${ }^{4}$ Department of Pharmaceutical Chemistry, Graduate School of Pharmaceutical Sciences, \\ Meiji Pharmaceutical University, Tokyo, Japan
}

\begin{abstract}
Background: A newly-synthesized derivative of renieramycin $M(R M)$, an anticancer lead compound isolated from the blue sponge Xestospongia sp., hydroquinone 5-Ocinnamoyl ester (CIN-RM), was investigated here for its activity against non-small cell lung cancer cells. Materials and Methods: Cytotoxicity effects of CIN-RM and RM on H292 lung cancer cells were determined by the MTT assay. We also investigated the mechanism of CIN-RM-mediated apoptosis and mechanism of action of this compound by western blotting. Results: CIN-RM showed more potent cytotoxicity than its parental compound (RM) against H292 lung cancer cells. At concentrations of 15-60 $\mu M, C I N-R M$ significantly induced apoptosis by increasing expression of apoptosis-inducing factor (AIF) and activation of caspase-3 and -9. For up-stream mechanism, CIN-RM mediated apoptosis through a p53dependent mechanism, that consequently down-regulated antiapoptotic B-cell lymphoma 2 (BCL2), while increasing the level of pro-apoptotic BCL2-associated $X(B A X)$. In addition, phosphorylation of pro-survival protein AKT was found to be dramatically reduced. Conclusion: This study revealed the potential of CIN-RM for apoptosis induction and in the development of a novel anticancer agent.
\end{abstract}

Correspondence to: Dr. Pithi Chanvorachote, Associate Professor, Department of Pharmacology and Physiology, Cell-Based Drug and Health Product Development Research Unit and Faculty of Pharmaceutical Sciences, Chulalongkorn University, Bangkok 10330, Thailand. Tel: +66 22188344, Fax: +66 22188340, e-mail: pithi.c@chula.ac.th and pithi_chan@yahoo.com

Key Words: Renieramycin M, hydroquinone 5-O-cinnamoyl ester analog of renieramycin $\mathrm{M}$, apoptosis, lung cancer, lead drug.
Lung cancer is the leading cause of cancer-mediated deaths, and $80-85 \%$ of all lung cancers are non-small cell lung cancer $(1,2)$. Importantly, resistance to anticancer drugs frequently found in patients with lung cancer has long been recognized as one of the most important obstacles to success of cancer therapy (3-5), leading to the urgent need for more effective chemotherapeutic agents.

The main mechanism of action of the currently effective chemotherapeutic drugs is to mediate cancer cell apoptosis. Apoptosic cell death can be triggered by the production of DNA adducts or damage signal that subsequently activates the p53-dependent cascade. The activation of p53 results in the increase of pro-apoptotic proteins which are members of B-cell lymphoma 2 (BCL2) family such as BCL2-associated $\mathrm{X}(\mathrm{BAX})$ accompanied by the reduction of anti-apoptotic proteins, including BCL2. The induction of pro-apoptotic signaling leads to the formation of mitochondrial pores, the release of cytochrome $c$ into the cytosol, the activation of caspases, and finally cell apoptosis (6-8). In contrast, resistance to apoptosis in lung cancer can be caused by several mechanisms; however, the up-regulation of expression of pro-survival proteins including ATP-dependent tyrosine kinase (AKT), and anti-apoptotic proteins of the BCL2 family were shown to be the predominant mechanisms (9-11).

In order to overcome drug resistance problems, our group has focused on searching for natural products with anticancer capability. Renieramycin M (RM), a bistetrahydroisoquinolinequinone alkaloid isolated from the Thai blue sponge Xestospongia sp., was reported to possess highly potent cytotoxicity against several human cancer cell lines, including lung, colon, prostate, breast, pancreatic, and oral cancer cells (12-15). Recently, RM was shown to have potent antimetastatic activity by sensitizing anoikis-resistant lung cancer 
cells to anoikis (16). In addition, RM was shown to suppress cancer stem-like phenotypes in lung cancer cells (17).

Recently, a series of 22- $O$-acyl and hydroquinone 5- $O$-acyl ester analogs of RM were synthesized. These RM derivatives were tested for structure-cytotoxicity relationship study in H292 and H460 non-small-cell lung cancer cell lines. (15, 18, 19). Interestingly, most $22-O$-acyl ester and hydroquinone 5 $O$-acyl ester analogs of RM exhibited potent cytotoxicity at nanomolar concentrations and several of them exhibited higher potency than RM. Having a unique aromatic ester substituent, hydroquinone 5-O-cinnamoyl ester (CIN-RM) is structurally attractive as a potential anticancer candidate. CINRM was obtained via two-step chemical synthesis involving Pd-catalyzed hydrogenation and esterification and the structural characterization was matched with the reported data (19). Herein, we investigated the effect of CIN-RM on lung cancer cells. This information may benefit the further development of new anticancer agents.

\section{Materials and Methods}

Preparation of CIN-RM. A solution of RM (15.0 mg, $0.026 \mathrm{mmol})$ in EtOAc $(10 \mathrm{ml})$ was added with $20 \% \mathrm{Pd}(\mathrm{OH})_{2}$ on carbon $(7.5 \mathrm{mg}$, $50 \% \mathrm{w} / \mathrm{w})$. A hydrogen balloon was attached to the reaction flask. The heterogeneous reaction was stirred vigorously at room temperature $\left(25^{\circ} \mathrm{C}\right)$ and $1 \mathrm{~atm}$ for $5 \mathrm{~h}$. The reaction was filtered through a pad of celite and washed with EtOAc (10 ml, 3 times $)$ and $\mathrm{CHCl}_{3}$ (10 ml, 3 times). The filtrates were combined and concentrated in vacuo to yield HQ-RM as a colorless solid. The product was employed in the next step without further purification. Next, the resulted HQ-RM was placed in an oven dried-rounded bottom flask. To a solution of HQ-RM $(15.0 \mathrm{mg}, 0.026 \mathrm{mmol})$ in dry $\mathrm{CH}_{2} \mathrm{Cl}_{2}(5 \mathrm{ml})$ was stirred at room temperature $\left(25^{\circ} \mathrm{C}\right)$ under $\mathrm{Ar}$ atmosphere. The reaction was added 1-ethyl-3-(3dimethylaminopropyl) carbodiimide hydrochloride (EDCI.HCl, 4.0 $\mathrm{mg}, 0.026 \mathrm{mmol}$ ) and 4-dimethylaminopyridine (DMAP, $3.2 \mathrm{mg}$, $0.026 \mathrm{mmol})$, followed by cinnamoyl chloride $(4.3 \mathrm{mg}, 0.026$ $\mathrm{mmol})$. The reaction mixture was stirred for $3 \mathrm{~h}$. After completion, the reaction mixture was quenched by addition of water $(5 \mathrm{ml})$. The organic layer was separated by separatory funnel and the aqueous layer was extracted with $\mathrm{CHCl} 3$ (10 ml, 3 times). The organic layers were combined, washed with brine $(30 \mathrm{ml})$, dried over anhydrous $\mathrm{Na}_{2} \mathrm{SO}_{4}$, filtered and concentrated in vacuo. Purification by the silica gel flash chromatography eluting with hexanes:EtOAc (3:1) gave $7.9 \mathrm{mg}(43 \%)$ of CIN-RM as a yellow amorphous solid. ${ }^{1} \mathrm{H}$ NMR $\left(\mathrm{CDCl}_{3}, 400 \mathrm{MHz}\right) \delta 7.8\left(1 \mathrm{H}, \mathrm{d}, J=16.0 \mathrm{~Hz}, \mathrm{CH}=\mathrm{CH} H_{\beta}\right), 7.6$ (2H, m, H-3'and H-5'), 7.5 (3H, m, H-2', H-6', and H-4'), 6.7 (1H, $\left.\mathrm{d}, J=16.0 \mathrm{~Hz}, \mathrm{C} H_{\alpha}=\mathrm{CH}\right), 6.0(1 \mathrm{H}, \mathrm{qq}, J=7.4,1.2 \mathrm{~Hz}, \mathrm{H}-26), 5.8$ $(1 \mathrm{H}, \mathrm{s}, \mathrm{OH}-8), 4.5(1 \mathrm{H}, \mathrm{d}, J=11.2 \mathrm{~Hz}, \mathrm{H}-22 \mathrm{~b}), 4.3(1 \mathrm{H}$, br t,$J=4.0$ $\mathrm{Hz}, \mathrm{H}-1), 4.1(1 \mathrm{H}, \mathrm{d}, J=2.0 \mathrm{~Hz}, \mathrm{H}-21), 4.1(1 \mathrm{H}, \mathrm{dd}, J=11.2,4.0 \mathrm{~Hz}$, $\mathrm{H}-22 \mathrm{a}), 4.0(1 \mathrm{H}$, br d, $J=3.6 \mathrm{~Hz}, \mathrm{H}-11), 3.9\left(3 \mathrm{H}, \mathrm{s}, 17-\mathrm{OCH}_{3}\right), 3.8$ $\left(3 \mathrm{H}, \mathrm{s}, 7-\mathrm{OCH}_{3}\right), 3.4(1 \mathrm{H}, \mathrm{dt}, J=7.2,2.0 \mathrm{~Hz}, \mathrm{H}-13), 3.2(1 \mathrm{H}, \mathrm{d}$, $J=12.0 \mathrm{~Hz}, \mathrm{H}-3), 2.8(1 \mathrm{H}, \mathrm{dd}, J=20.8,7.2 \mathrm{~Hz}, \mathrm{H}-14 \alpha), 2.6(1 \mathrm{H}, \mathrm{dd}$, $J=14.0,2.0 \mathrm{~Hz}, \mathrm{H}-4 \alpha), 2.3(1 \mathrm{H}, \mathrm{d}, J=20.8 \mathrm{~Hz}, \mathrm{H}-14 \beta), 2.3(3 \mathrm{H}, \mathrm{s}$, $\left.12-\mathrm{NCH}_{3}\right), 2.1\left(3 \mathrm{H}, \mathrm{s}, 6-\mathrm{CH}_{3}\right), 1.9\left(3 \mathrm{H}, \mathrm{dq}, \mathrm{J}=7.2,1.4 \mathrm{~Hz}, \mathrm{H}_{3}-27\right)$, $1.9\left(3 \mathrm{H}, \mathrm{s}, 16-\mathrm{CH}_{3}\right), 1.7\left(3 \mathrm{H}, \mathrm{dq}, J=1.4,1.2 \mathrm{~Hz}, \mathrm{H}_{3}-28\right), 1.7(1 \mathrm{H}$, overlapped, $\mathrm{H}-4 \beta) ;{ }^{13} \mathrm{C}$ NMR $\left(\mathrm{CDCl}_{3}, 100 \mathrm{MHz}\right) \delta 186.0(\mathrm{C}-15)$,
182.6 (C-18), 167.1 (C-24), 164.7 (5-OC=O), 155.5 (C-17), 146.8 $\left(\mathrm{CH}=\mathrm{CH}_{\beta}\right), 143.8(\mathrm{C}-7), 143.1(\mathrm{C}-8), 141.5(\mathrm{C}-20), 140.0(\mathrm{C}-26)$, 139.1 (C-5), 135.7 (C-19), 134.1 (C-1'), 131.0 (C-4'), 129.1 (C-2' and C-6'), 128.8 (C-16), 128.4 (C-3' and C-5'), 126.8 (C-25), 124.5 $(\mathrm{C}-10), 122.6(\mathrm{C}-6), 117.6(21-\mathrm{CN}), 117.2(\mathrm{C}, \mathrm{C}-9), 116.4$ $\left(\mathrm{CH}_{\alpha}=\mathrm{CH}\right), 64.5(\mathrm{C}-22), 61.2\left(7-\mathrm{OCH}_{3}\right), 60.6\left(17-\mathrm{OCH}_{3}\right), 59.5(\mathrm{C}-$ 21), 56.5 (C-1), 55.3 (C-3), 54.9 (C-13), 54.6 (C-11), 41.5 (12$\left.\mathrm{NCH}_{3}\right), 27.8$ (C-4), 21.1 (C-14), 20.6 (C-28), 15.9 (C-27), 10.1 (6$\left.\mathrm{CH}_{3}\right)$, $8.6\left(16-\mathrm{CH}_{3}\right)$. Chemicals were purchased from Tokyo Chemical Industry. NMR spectroscopy was performed on JEOLJNM AL 400 FT-NMR spectrometer (19).

Chemicals. Hoechst 33342, 3-(4,5-dimethylthiazol-2-yl)-2,5diphenyltetrazolium bromide (MTT), dimethysulfoxide (DMSO), trypsin and phosphate-buffered saline (PBS) were obtained from Sigma Chemical, Inc. (St. Louis, MO, USA). Antibodies to apoptosis-inducing factor (AIF), phosphorylated AKT (p-AKT), total AKT, p53, BCL2, BAX, poly ADP ribose polymerase (PARP), caspase- 3 , caspase- 9 , and $\beta$-actin were obtained from Cell Signaling Technology, Inc. (Danvers, MA, USA).

Cell culture and treatment. H292 Non-small cell lung cancer cells were obtained from the American Type Culture Collection (Manassas, VA, USA) and cultured in RPMI medium supplemented with $10 \%$ fetal bovine serum, 2 mmol/l L-glutamine and 100 units $/ \mathrm{ml}$ penicillin/streptomycin. Cells were maintained in a humidified incubator containing $5 \% \mathrm{CO}_{2}$ at $37^{\circ} \mathrm{C}$. Compounds were dissolved in DMSO and achieve the working concentrations $(0,15$, 30 and $60 \mu \mathrm{M})$. DMSO in the working solution was less than $0.1 \%$ and showed no toxicity towards $\mathrm{H} 292$ cells.

Cell viability assay. Cell viability was determined by the MTT assay, which measures the cellular capacity to reduce MTT (yellow) to formazan crystals (purple) by mitochondria dehydrogenase. After $24 \mathrm{~h}$ treatment, the medium was replaced by $100 \mu \mathrm{l} /$ well of MTT solution $(0.4 \mathrm{mg} / \mathrm{ml})$ and the cells were incubated for $4 \mathrm{~h}$ at $37^{\circ} \mathrm{C}$. Subsequently, the MTT solution was removed and a $100 \mu \mathrm{l} /$ well of DMSO were added to dissolve the formazan crystals. The intensity was measured at $570 \mathrm{~nm}$ using a microplate reader (SpectraMax ${ }^{\circledR}$ M5, Molecular Devices, City, Ca, USA). All analyses were performed in at least three independent replicate cultures. The cell viability was calculated from the ratio of the optical density (OD) of treated to non-treated control cells and is presented as a percentage of the non-treated controls.

Nuclear staining assay. Cells were treated without or with different concentrations of CIN-RM in RPMI with serum for $24 \mathrm{~h}$ at $37^{\circ} \mathrm{C}$. Apoptotic and necrotic cell death was determined by Hoechst 33342 staining: cells were incubated with $10 \mu \mathrm{M}$ of Hoechst 33342 dye for $30 \mathrm{~min}$ at $37^{\circ} \mathrm{C}$ in the dark. Finally, cells were visualized under a fluorescence microscope (Olympus IX51 with DP70; Olympus, Center Valley, PA, USA). The blue fluorescent Hoechst dye was used for detection of nuclear condensation and DNA fragmentation in apoptosis cell. The data are presented as the percentage of apoptosis as follows: Apoptosis $(\%)=$ (number of apoptotic cells $\times 100) /$ number of total cells

Membrane integrity analysis. The cells collected after treatment with compounds were stained with trypan blue dye and subsequently morphologically visualized and quantified under an 

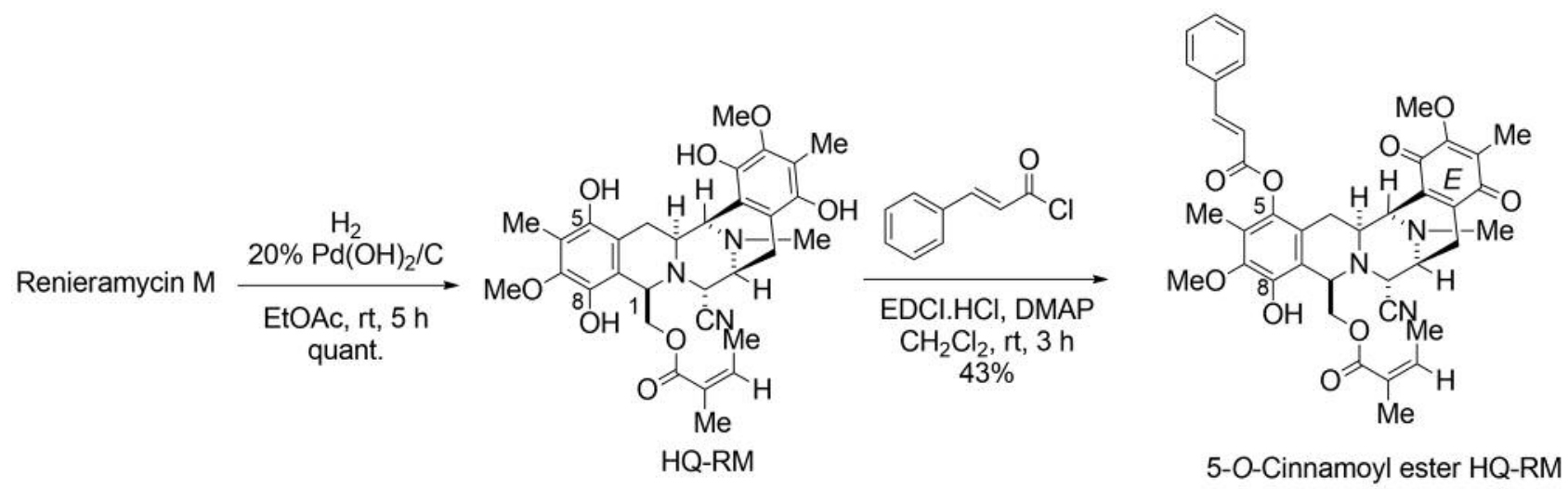

Figure 1. The synthesis of 5-O-cinnamoyl ester analog of renieramycin $M(C I N-R M)$. CIN-RM was derived from hydrogenation of renieramycin $M$ with $20 \% \mathrm{Pd}(\mathrm{OH}) 2 / \mathrm{C}$ in ethyl acetate for 5 h to obtain the bishydroquinonerenieramycin $M(H Q-R M)$. HQ-RM was subjected to esterification with cinnamoyl chloride in the presence of 1-ethyl-3-(3-dimethylaminopropyl)carbodiimide hydrochloride (EDCI.HCl) and 4-dimethylaminopyridine (DMAP) yielding CIN-RM.

automated cell counter (TC10 automated cell counter; Bio-Rad, Hercules, CA, USA).

Western blot analysis. Treated and untreated cells were harvested and lysed on ice for $60 \mathrm{~min}$. The protein content of cell lysate was determined using BSA protein assay kit (Pierce, Rockford, IL, USA). An equal amount of protein from each sample was separated by size using sodium dodecyl sulfate-polyacrylamide gel electrophoresis and then transferred into nitrocellulose membranes. The membrane was blocked in 5\% skim milk in $25 \mathrm{mmol} / \mathrm{l}$ Tris- $\mathrm{HCl}(\mathrm{pH} \mathrm{7.4)}, 125$ $\mathrm{mmol} / 1 \mathrm{NaCl}$ and $0.1 \%$ Tween $20 \mathrm{TBST}$ ) for $1 \mathrm{~h}$ at room temperature and then probed with appropriate primary antibodies at $4^{\circ} \mathrm{C}$ overnight. Subsequently, the membrane was washed three times with TBST for $8 \mathrm{~min}$ then incubated with horseradish peroxidaseconjugated secondary antibodies according to the primary antibodies for $2 \mathrm{~h}$ at room temperature. The signal of immunoreactive proteins was detected by enhanced chemiluminescence (Supersignal West Pico; Pierce, Rockford, IL, USA). Protein expression was investigated and $\beta$-actin was used as a loading of control in each treatment. Subsequently, the bands were then visualized using a film exposure with a chemiluminescence detection system and were quantified with analystPC densitometric software.

Statistical analysis. Mean data from at least three independent experiments were normalized to result for the non-treated control. All data are presented as the mean \pm standard error of the mean (S.E.M.). Statistical differences between means were determined using analysis of variance (ANOVA) and post hoc test at a significance level of $p<0.05$.

\section{Results}

Evaluation of the cytotoxic effect of CIN-RM and RM on $H 292$ cells. CIN-RM was synthesized from RM as shown in Figure 1.

The cytotoxicity of CIN-RM and its parental compound RM was characterized by treating $\mathrm{H} 292$ cells with different concentrations of compounds $(0-100 \mu \mathrm{M})$ for $24 \mathrm{~h}$, then cell viability was measured by MTT assay. Figure 2A shows that a concentration of $100 \mu \mathrm{M}$ of CIN-RM significantly reduced viability of $\mathrm{H} 292$ cells to approximately $40 \%$ when compared with $62 \%$ with RM at the same concentration. To confirm effect of CIN-RM in mediating cell death, after $24 \mathrm{~h}$ of treatment with 0-100 $\mu \mathrm{M}$ of CIN-RM, the cells were collected, stained with trypan blue dye, and subsequently morphologically visualized, and quantified by an automated cell counter (Figure 2B-C).

CIN-RM induces apoptotic cell death. In order to investigate the apoptosis inducing effect of CIN-RM, cells were exposed to CIN-RM and apoptosis was evaluated by Hoechst 33342 staining assay. The nuclear staining assay indicated that $15-$ $60 \mu \mathrm{M}$ of CIN-RM caused a significant increase in the number of cells with condensed or fragmented nuclei compared with non-treated control cells (Figure 3A and B). At a concentration of $60 \mu \mathrm{M}, \mathrm{CIN}-\mathrm{RM}$-induced cell apoptosis was approximately $55 \%$.

To confirm the above apoptotic activity of CIN-RM, the hallmarks of apoptosis including cleavage of PARP, induction of AIF expression, and activation of caspase- 3 and caspase-9 were investigated in cells treated with CIN-RM. Western blot analysis indicated that treatment of $\mathrm{H} 292$ cells with CIN-RM increased production of cleaved PARP, while reducing the total intact PARP. Consistent with this, CIN-RM up-regulated AIF and increased activation of caspase- 3 and caspase-9 in a dose-dependent manner (Figure 3C and D). Taken together, these results show that CIN-RM induced apoptosis of H292 lung cancer cells.

CIN-RM triggers apoptosis via a p53-dependent mechanism and suppresses $A K T$. It is known that apoptosis induction 
A

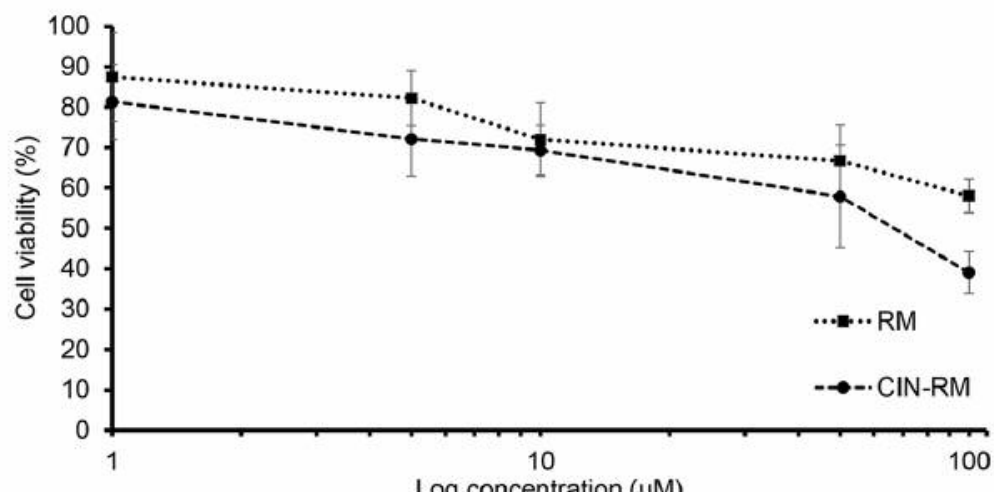

B

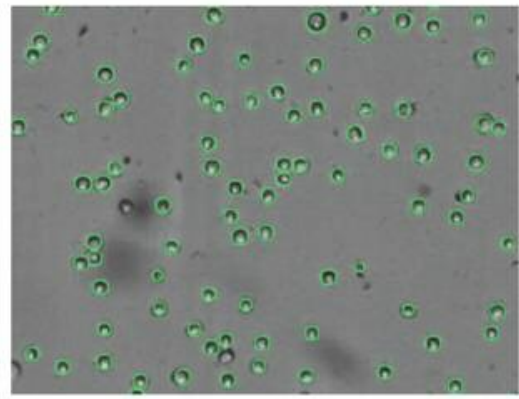

Control

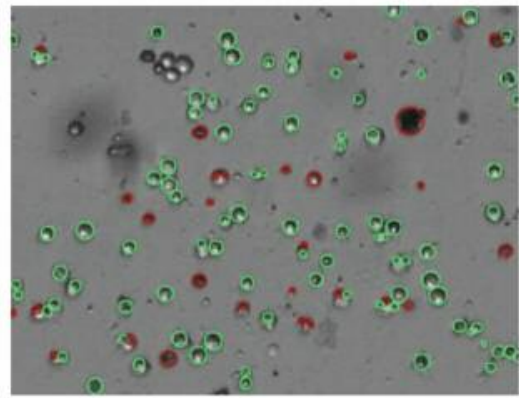

CIN-RM $30 \mu \mathrm{M}$

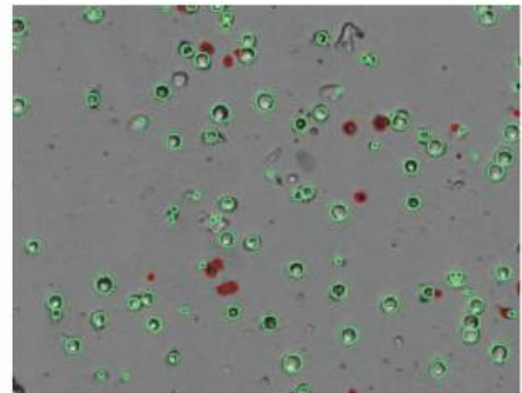

CIN-RM $5 \mu \mathrm{M}$

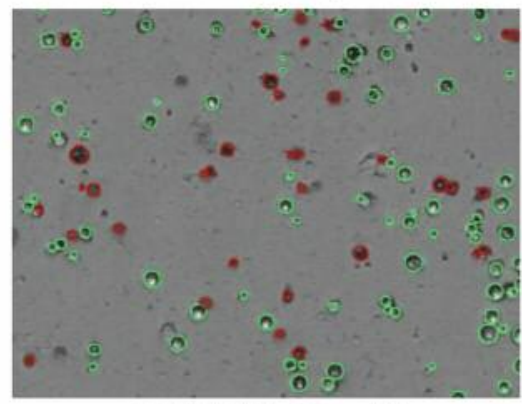

CIN-RM $60 \mu \mathrm{M}$

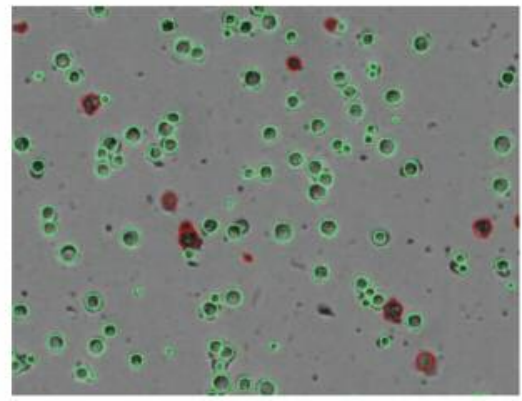

CIN-RM $15 \mu \mathrm{M}$

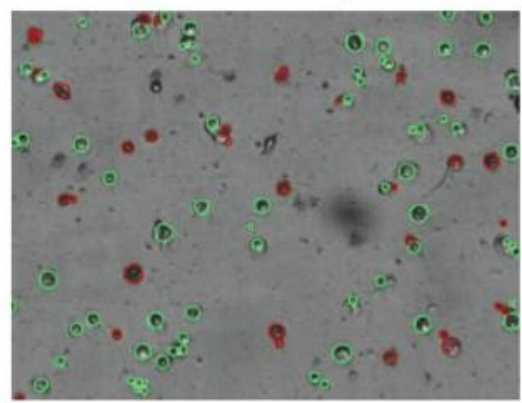

CIN-RM $100 \mu \mathrm{M}$

C

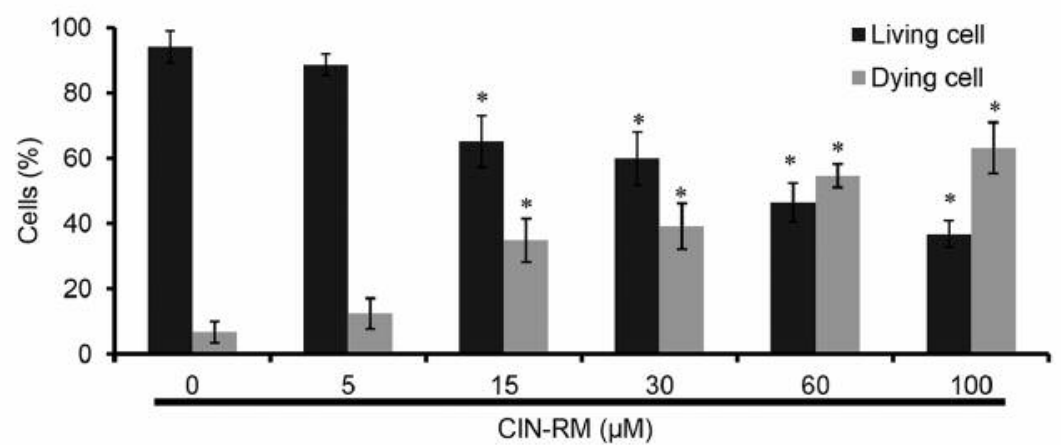

Figure 2. Cytotoxic effect of 5-O-cinnamoyl ester analog of renieramycin M (CIN-RM) on H292 lung cancer cells. A: H292 Human lung cancer cells were treated with different concentrations $(0-100 \mu M)$ of $C I N-R M$ or $R M$ for $24 \mathrm{~h}$. The percentage of cell viability was analyzed. Data represent the mean $\pm S D(n=3)$. Significantly different at $* p<0.05$ versus non-treated control. B: H292 cells collected after treatment with CIN-RM (0-100 $\mu M)$ for $24 \mathrm{~h}$ were stained with trypan blue dye and subsequently analyzed cell membrane integrity under an automated cell counter. The green color indicates living cells, while the red color indicates dying cells. C: The percentage of living cells and dying cells after treatment with CIN-RM (O$100 \mu M)$ for 24 h were quantified. Data represent the mean $\pm S D(n=3)$. Significantly different at $* p<0.05$ versus the non-treated control. 
A
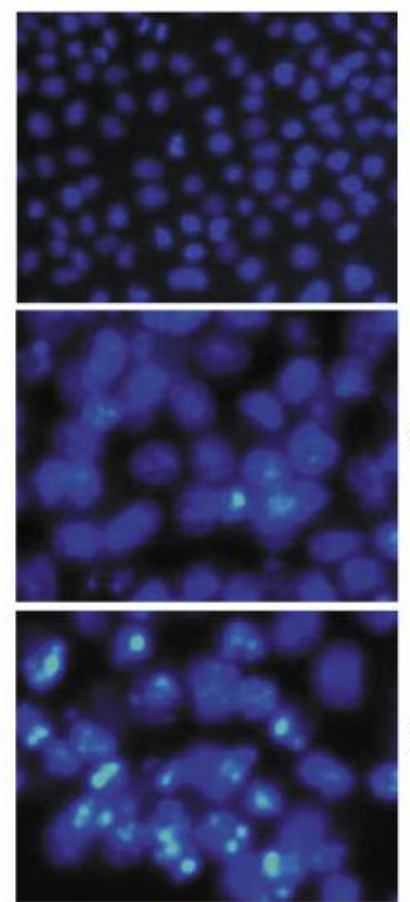

15

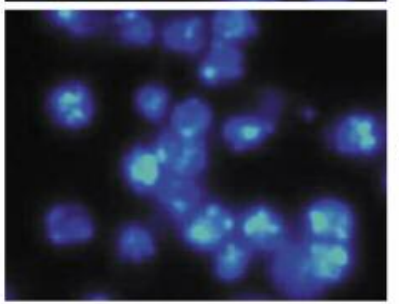

30

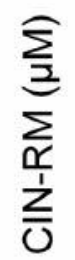

60

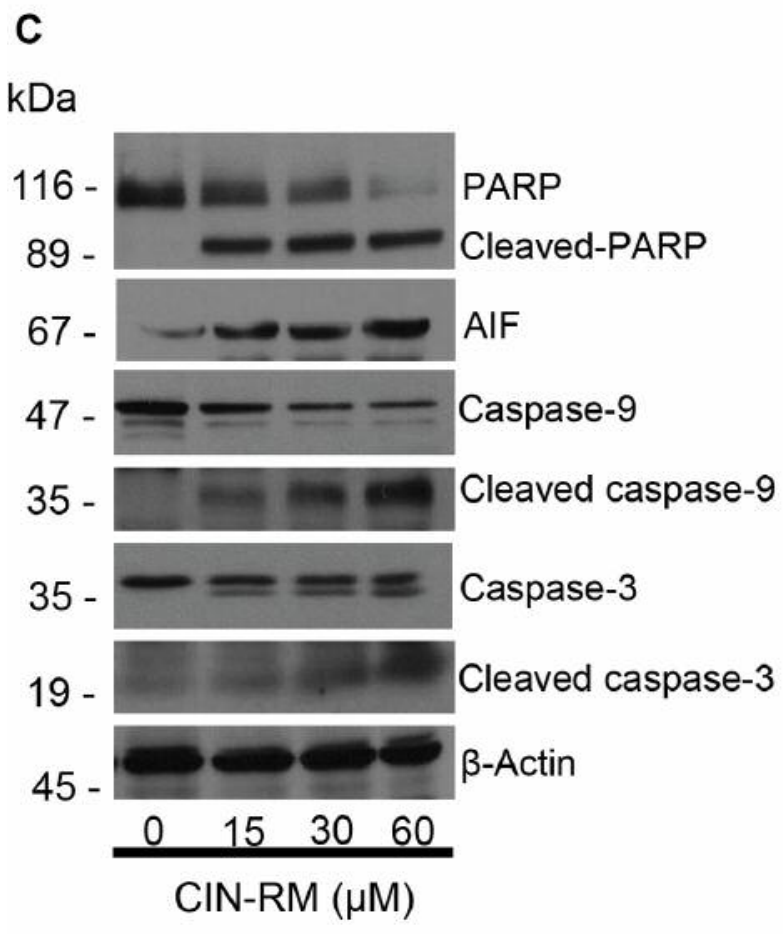

B

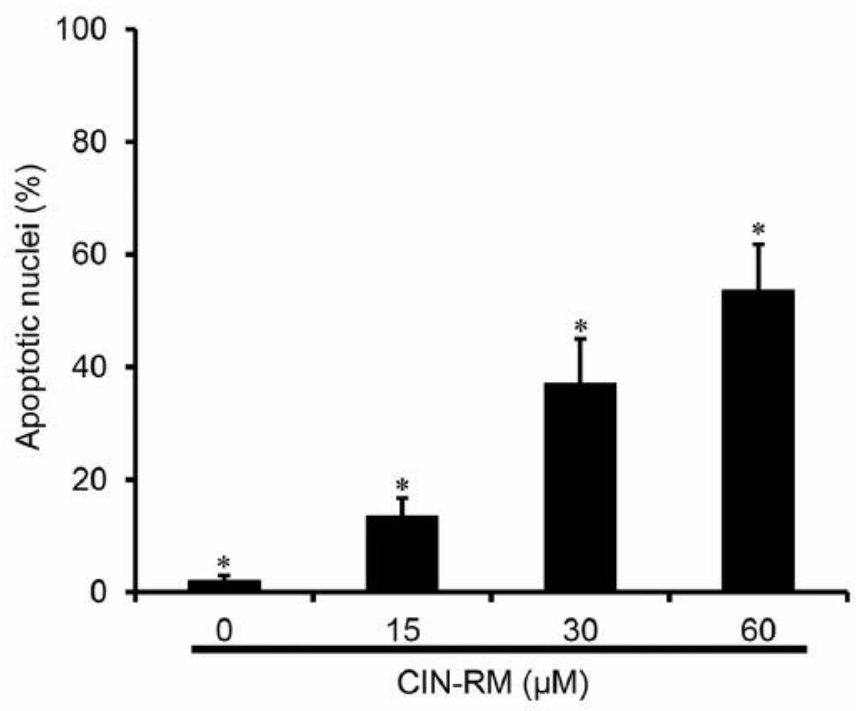

D

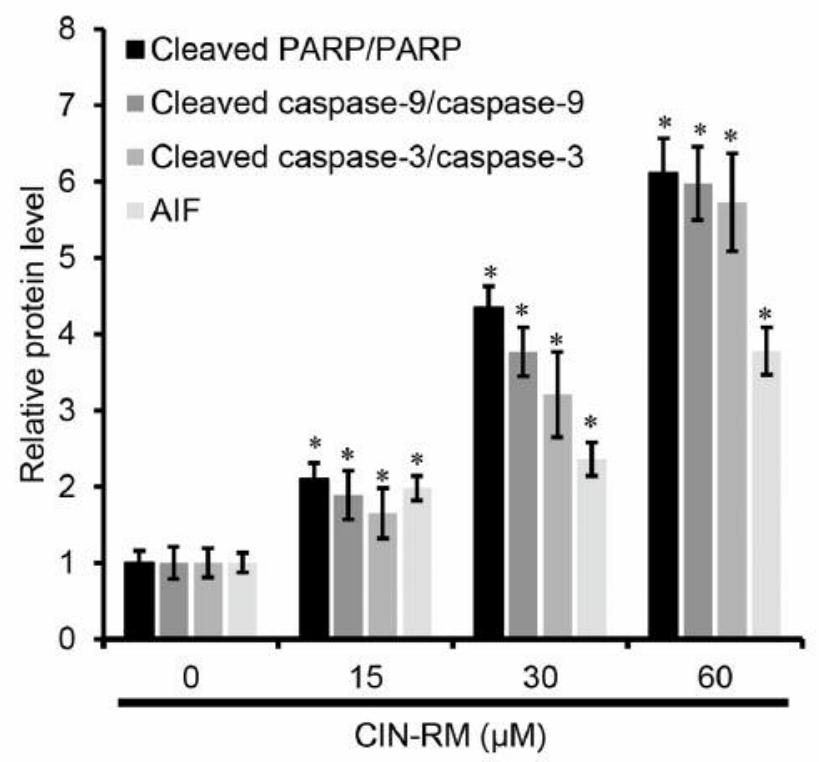

Figure 3. Apoptosis induction by 5-O-cinnamoyl ester analog of renieramycin M (CIN-RM). A: H292 cells were exposed to CIN-RM for $24 h$ and subsequently apoptosis was evaluated by Hoechst 33342 staining assay. B: The percentage of apoptotic cells was quantified. Data represent the mean $\pm S D(n=3)$. Significantly different at $* p<0.05$ versus the non-treated control. C: $\mathrm{H} 292$ cells were treated with CIN$R M(0,15,30$ and $60 \mu M)$ for $24 \mathrm{~h}$. The expression of apoptosis-related proteins in $\mathrm{H} 292$ cells was determined by western blotting. The blots were reprobed with $\beta$-actin to confirm equal loading of samples. $D$ : The immunoblot signals were quantified by densitometry and data from independent experiments were normalized and are presented. The data are mean $\pm S D(n=3)$. Significantly different at $* p<0.05$ versus nontreated cells. 
A

$\mathrm{kDa}$

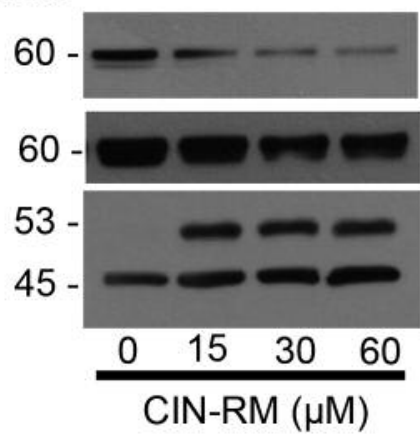

p-AKT (s473)

AKT

p53

$\beta$-Actin

B

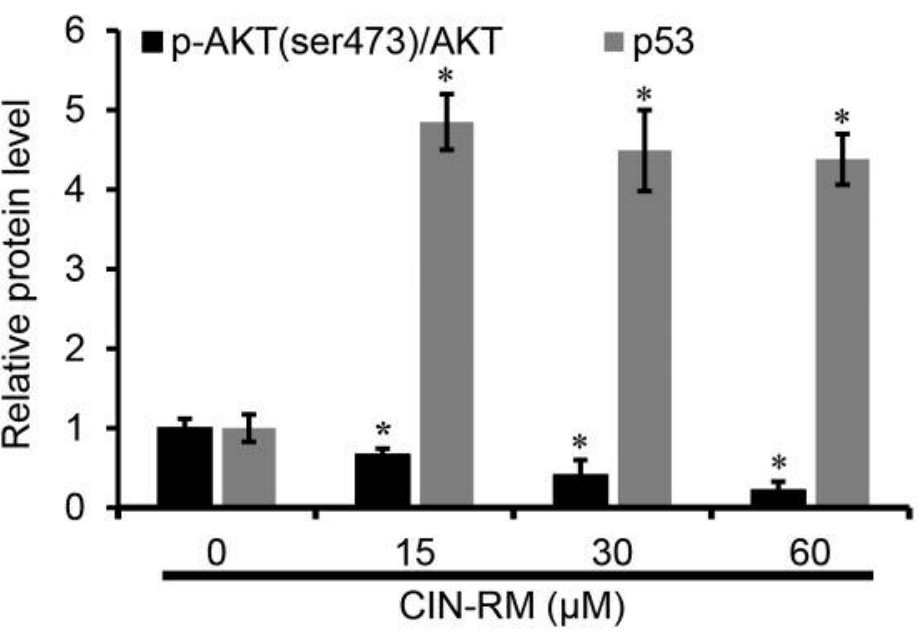

C

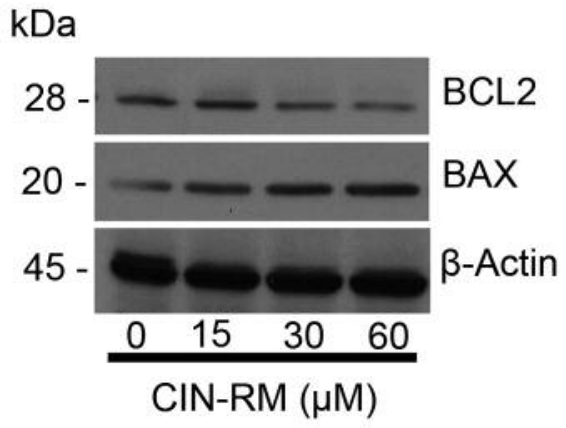

D

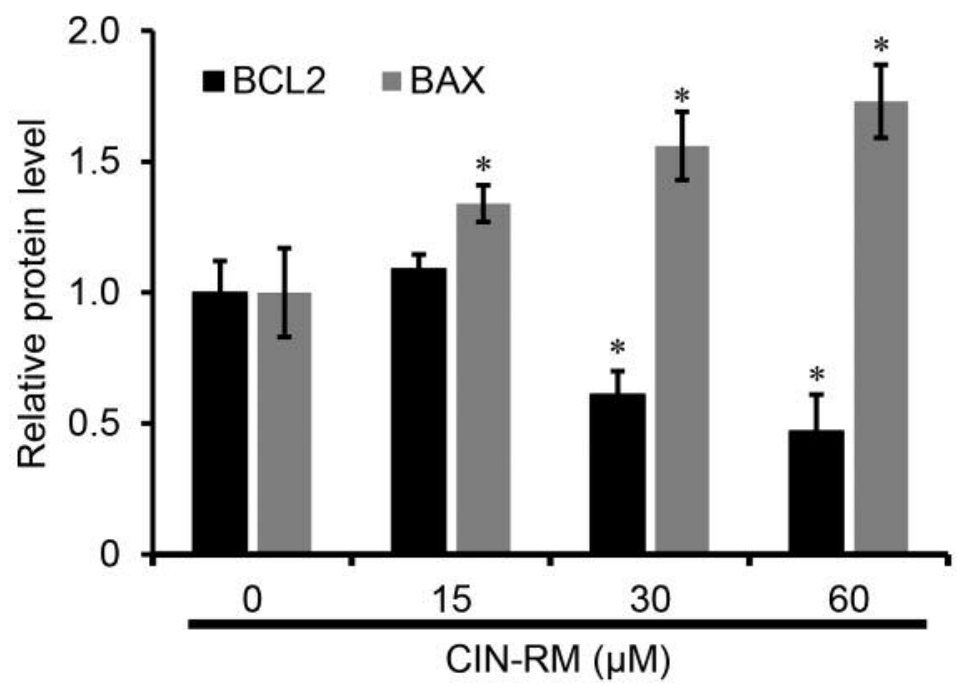

Figure 4. 5-O-Cinnamoyl ester analog of renieramycin $M(C I N-R M)$ induces apoptosis through accumulation of p53 and suppresses ATP-dependent tyrosine kinase (AKT). H292 cells were treated with CIN-RM $(0,15,30$ and $60 \mu M)$ for $12 \mathrm{~h}$. A: The expression of AKT and phosphorylated (active) $A K T$ [p-AKT(s473)] was determined by western blot assay. The blots were reprobed with $\beta$-actin to confirm equal loading of samples. B: The immunoblot signals were quantified by densitometry and data from independent experiments were normalized and are presented. The data are mean $\pm S D(n=3)$. Significantly different at $* p<0.05$ versus non-treated cells. $C$ : The expression of anti-apoptotic proteins B-cell lymphoma 2 (BCL2) and pro-apoptotic proteins BCL2-associated $X(B A X)$ were determined by western blotting. The blots were reprobed with $\beta$-actin to confirm equal loading of samples. D: The immunoblot signals were quantified by densitometry and data from independent experiments were normalized and are presented. The data are mean $\pm S D(n=3)$. Significantly different at $* p<0.05$ versus non-treated cells.

caused by several chemotherapeutic drugs occurs through p53-mediated death (20-22). A number of studies have indicated the effect of pro-survival AKT signal on chemotherapeutic resistance in cancer $(9,10,23,24)$. Therefore, we tested whether CIN-RM induced apoptosis of H292 cells via p53 and suppressed pro-survival AKT. Cells were treated with CIN-RM $(0-60 \mu \mathrm{M})$ for $12 \mathrm{~h}$, and subjected to western blot analysis for the detection of p-AKT, total AKT, p53, BCL2, and BAX. Figure 4 shows that treatment of the cells with CIN-RM dramatically suppressed active AKT (AKT phosphorylated at Ser473), while slightly suppressing total AKT. Importantly, CIN-RM increased the p53 level in the cells relative to the untreated control. As a down-stream protein target of p53 pathway, 


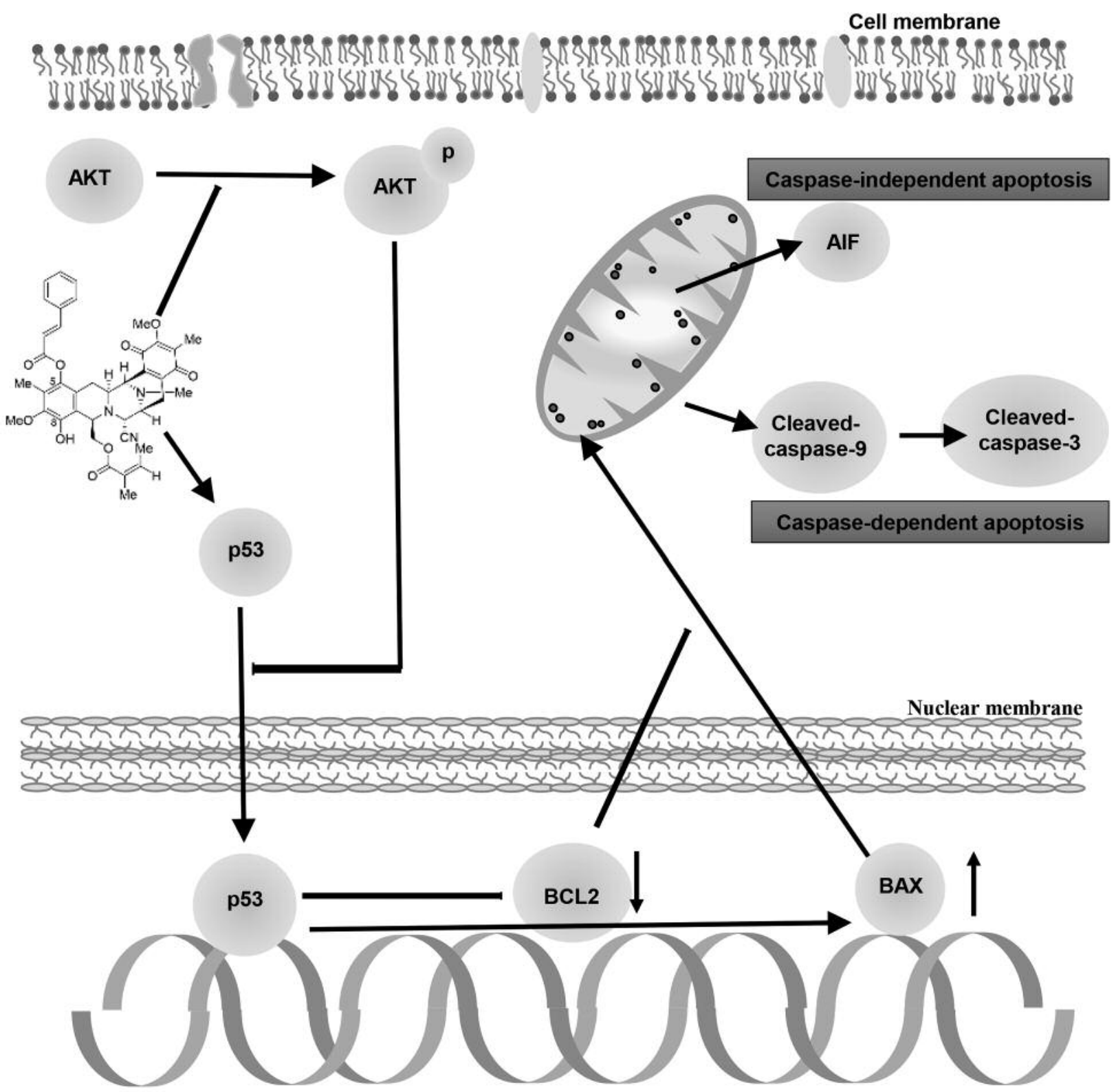

Figure 5. Schematic overview of apoptosis pathway of 5-O-cinnamoyl ester analog of renieramycin M (CIN-RM). CIN-RM causes apoptosis by reducing expression of pro-survival ATP-dependent tyrosine kinase (AKT) and activating the p53 pathway. The accumulation of p53 suppresses the expression of anti-apoptotic protein B-cell lymphoma 2 (BCL2) while promoting the expression of pro-apoptotic protein BCL2-associated X (BAX). The shift of balance between pro- and anti-apoptotic proteins subsequently triggers the release of apoptosis-inducing factor (AIF), which promotes caspase-independent apoptosis pathway. Moreover, loss of mitochondrial membrane integrity stimulates caspase-dependent apoptosis by activation of caspase-9 and caspase-3.

expression of BAX was found to subsequently increase, while that of BCL2 was down-regulated (Figure 4C and D). Together, these results indicate that CIN-RM induces apoptosis by activating the p53 pathway as well as suppressing the AKT survival signal.

\section{Discussion}

New drugs and novel strategies to overcome cancer with high efficacy are of the greatest interest in cancer-related and pharmacological research fields. In general, most anticancer drugs are used to kill cancer cells through 
apoptosis, as it is a mode of cell death with a controlling mechanism $(22,25)$. Apoptosis is the main mechanism that the human body uses to eliminate unwanted and damaged cells $(26,27)$. As part of our continuing searching for novel cytotoxic natural products, we isolated and modified a series of renieramycin (RM) alkaloids from blue sponge Xestospongia sp. $(12,13,15,18)$. RMs are a group of bistetrahydro-isoquinoline quinone alkaloids possessing potent cytotoxicity against several human cancer cell lines (15-18, 28-29). In addition, RM was shown to have antimetastasis potential and suppress cancer stem cells in lung cancer $(16,17,28)$.

Successful synthesis of 22- $\mathrm{O}$-acyl and hydroquinone 5-Oacyl ester analogs of RM has led to several more potent compounds for anticancer approaches $(15,18,19)$. Interestingly, our previous work of RM derivatives showed that the hydroquinone 5-O-acetyl ester analog of RM was the first analog possessing selective apoptotic induction while reduce its necrosis-inducing effect by reducing oxidative stress (30).

As chemotherapeutic resistance in lung cancer has been long recognized as an important obstacle to successful therapy $(9,31)$, new drugs having high potency as well as the ability to inhibit drug resistance of cancer cells are of great interest in anticancer drug discovery. The AKT signaling pathway has been shown to be a central survival pathway playing a key role in drug resistance in many cancer types, including lung cancer $(32,33)$. Especially, targeting of the AKT pathway was shown to be a good strategy to boost chemotherapy efficacy (34). Figure 5 indicates that not only does CIN-RM induce apoptosis of lung cancer cells by activation of a p53-dependent mechanism that triggers BCL2 imbalance, the release of AIF, and activation of caspases, but the compound also has the ability to suppress the AKT survival signal.

In conclusion, we have shown that the newly-synthesized CIN-RM has a potent cytotoxic effect against lung cancer cells. The results indicate that the derivative of the lead compound RM possesses a good anticancer activity by inducing apoptosis of lung cancer cells via p53-mediated alteration of BCL2 protein expression and suppression of pro-survival AKT signaling.

\section{Conflicts of Interest}

The Authors declare that there is no conflict of interest in regard to this research.

\section{Acknowledgements}

This work was supported by grants from The Thailand Research Fund through The Royal Golden Jubilee Ph.D. program Grant No. PHD/0063/2557, grant for International Research Integration: Chula Research Scholar, Ratchadaphiseksomphot Endowment Fund grant for Ratchadaphiseksomphot Endowment Fund under Outstanding Research Performance Program.

\section{References}

1 Esposito L, Conti D, Ailavajhala R, Khalil N and Giordano A: Lung cancer: Are we up to the challenge? Curr Genomics 11: 513-518, 2010

2 World Cancer Factsheet. London: International Agency for Research on Cancer and Cancer Research UK, 2012.

3 Shanker M, Willcutts D, Roth JA and Ramesh R: Drug resistance in lung cancer. Lung Cancer: Targets Ther 1: 23-36, 2010.

4 Dai PC, Liu DL, Zhang L, Ye J, Wang Q, Zhang HW, Lin XH and Lai GX: Astragaloside IV sensitizes non-small cell lung cancer cells to gefitinib potentially via regulation of SIRT6. Tumour Biol 39: 1-6, 2017.

5 Martinez-Jimenez F, Overington JP, Al-Lazikani B and MartiRenom MA: Rational design of non-resistant targeted cancer therapies. Sci Rep 7: 1-18, 2017.

6 Wang C and Youle RJ: The role of mitochondria in apoptosis. Annu Rev Genet 43: 95-118, 2009.

7 Liu C, Wang Y, Xie S, Zhou Y, Ren X, Li X and Cai Y: Liquiritigenin induces mitochondria-mediated apoptosis via cytochrome $c$ release and caspases activation in HeLa Cells. Phytother Res 25: 277-283, 2011.

8 Tait SWG and Green DR: Mitochondrial regulation of cell death. Cold Spring Harb Perspect Biol 5: a008706, 2013.

9 Jones VS, Huang R-Y, Chen L-P, Chen Z-S, Fu L and Huang R$P$ : Cytokines in cancer drug resistance: Cues to new therapeutic strategies. Biochim Biophys Acta 1865: 255-265, 2016.

10 Luanpitpong S and Chanvorachote P: Nitric oxide and aggressive behavior of lung cancer cells. Anticancer Res 35: 4585-4592, 2015.

11 Narayanan KB, Ali M, Barclay BJ, Cheng Q, D’Abronzo L, Dornetshuber-Fleiss R, Ghosh PM, Gonzalez Guzman MJ, Lee T-J, Leung PS, Li L, Luanpitpong S, Ratovitski E, Rojanasakul Y, Romano MF, Romano S, Sinha RK, Yedjou C, Al-Mulla F, Al-Temaimi R, Amedei A, Brown DG, Ryan EP, Colacci AM, Hamid RA, Mondello C, Raju J, Salem HK, Woodrick J, Scovassi A, Singh N, Vaccari M, Roy R, Forte S, Memeo L, Kim SY, Bisson WH, Lowe L and Park HH: Disruptive environmental chemicals and cellular mechanisms that confer resistance to cell death. Carcinogenesis 36: S89-S110, 2015.

12 Suwanborirux K, Amnuoypol S, Plubrukarn A, Pummangura S, Kubo A, Tanaka C and Saito N: Chemistry of renieramycins. Part 3. Isolation and structure of stabilized renieramycin type derivatives possessing antitumor activity from Thai sponge Xestospongia species, pretreated with potassium cyanide. J Nat Prod 66: 1441-1446, 2003.

13 Amnuoypol S, Suwanborirux K, Pummangura S, Kubo A, Tanaka C and Saito N: Chemistry of renieramycins. Part 5. Structure elucidation of renieramycin-type derivatives $\mathrm{O}, \mathrm{Q}, \mathrm{R}$ and $\mathrm{S}$ from Thai marine sponge Xestospongia species pretreated with potassium cyanide. J Nat Prod 67: 1023-1028, 2004.

14 Saito N, Tanaka C, Koizumi Y-i, Suwanborirux K, Amnuoypol S, Pummangura $\mathrm{S}$ and Kubo A: Chemistry of renieramycins. Part 6: Transformation of renieramycin $\mathrm{M}$ into jorumycin and renieramycin $\mathrm{J}$ including oxidative degradation products, mimosamycin, renierone and renierol acetate. Tetrahedron 60 : 3873-3881, 2004. 
15 Charupant K, Daikuhara N, Saito E, Amnuoypol S, Suwanborirux K, Owa $\mathrm{T}$ and Saito N: Chemistry of renieramycins. Part 8: synthesis and cytotoxicity evaluation of renieramycin $\mathrm{M}$-jorunnamycin A analogues. Bioorg Med Chem 17: 4548-4558, 2009.

16 Sirimangkalakitti N, Chamni S, Suwanborirux $\mathrm{K}$ and Chanvorachote $\mathrm{P}$ : Renieramycin $\mathrm{M}$ sensitizes anoikis-resistant h460 lung cancer cells to anoikis. Anticancer Res 36: 1665-1671, 2016.

17 Sirimangkalakitti N, Chamni S, Suwanborirux K and Chanvorachote P: Renieramycin $\mathrm{M}$ attenuates cancer stem celllike phenotypes in h460 lung cancer cells. Anticancer Res 37: 615-621, 2017.

18 Sirimangkalakitti N, Chamni S, Charupant K, Chanvorachote P, Mori N, Saito $N$ and Suwanborirux K: Chemistry of renieramycins. 15. Synthesis of 22-O-ester derivatives of jorunnamycin A and their cytotoxicity against non-small-cell lung cancer cells. J Nat Prod 79: 2089-2093, 2016.

19 Chamni S, Sirimangkalakitti N, Chanvorachote P, Saito N and Suwanborirux K: Chemistry of renieramycins. 17. A new generation of renieramycins: hydroquinone 5-O-monoester analogues of renieramycin $\mathrm{m}$ as potential cytotoxic agents against non-small-cell lung cancer cells. J Nat Prod, 2017. doi:10.1021/acs.jnatprod.7b00068 [Epub ahead of print]

20 Fiandalo MV and Kyprianou N: Caspase control: protagonists of cancer cell apoptosis. Exp Oncol 34: 165-175, 2012.

21 Ricci MS and Zong W-X: Chemotherapeutic approaches for targeting cell death pathways. Oncologist 11: 342-357, 2006.

22 Johnstone RW, Ruefli AA and Lowe SW: Apoptosis: a link between cancer genetics and chemotherapy. Cell 108: 153-164, 2002.

23 Fresno Vara JA, Casado E, Castro J, Cejas P, Belda-Iniesta C, and González-Barón M: PI3K/AKT signaling pathway and cancer. Cancer Treat Rev 30: 193-204, 2004.

24 Ghadimi MP, Lopez G, Torres KE, Belousov R, Young ED, Liu J et al: Targeting the PI3K/mTOR axis, alone and in combination with autophagy blockade, for the treatment of malignant peripheral nerve sheath tumors. Mol Cancer Ther 11: 1758-1769, 2012.

25 Lopez J and Tait SWG: Mitochondrial apoptosis: killing cancer using the enemy within. Br J Cancer 112: 957-962, 2015.
26 Elmore S: Apoptosis: a review of programmed cell death. Toxicologic pathology 35: 495-516, 2007.

27 Fuchs Y and Steller H: Programmed cell death in animal development and disease. Cell 147: 742-758, 2011.

28 Halim H, Chunhacha P, Suwanborirux K and Chanvorachote P: Anticancer and antimetastatic activities of renieramycin $\mathrm{M}$, a marine tetrahydroisoquinoline alkaloid, in human non-small cell lung cancer cells. Anticancer Res 31: 193-201, 2011.

29 Pinkhien T, Maiuthed A, Chamni S, Suwanborirux K, Saito N and Chanvorachote $\mathrm{P}$ : Bishydroquinone renieramycin $\mathrm{M}$ induces apoptosis of human lung cancer cells through a mitochondriadependent pathway. Anticancer Res 36: 6327-6333, 2016.

30 Cheun-Arom T, Chanvorachote P, Sirimangkalakitti N, Chuanasa T, Saito N, Abe I, and Suwanborirux K: Replacement of a quinone by a $5-O$ - acetylhydroquinone abolishes the accidental necrosis-inducing effect while preserving the apoptosis-inducing effect of renieramycin $\mathrm{M}$ on lung cancer cells. J Nat Prod 76: 1468-1474, 2013.

31 Sui X, Chen R, Wang Z, Huang Z, Kong N, Zhang M, Han W, Lou F, Yang J, Zhang Q, Wang X, He C and Pan H: Autophagy and chemotherapy resistance: a promising therapeutic target for cancer treatment. Cell Death Dis 4: e838, 2013.

32 David O, Jett J, LeBeau H, Dy G, Hughes J, Friedman M and Brody AR: Phospho-AKT overexpression in non-small cell lung cancer confers significant stage-independent survival disadvantage. Clin Cancer Res 10: 6865-6871, 2004.

33 Tsvetkova E and Goss GD: Drug resistance and its significance for treatment decisions in non-small-cell lung cancer. Curr Oncol 19: S45-S51, 2012.

34 Grand ML, Berges R, Pasquier E, Montero MP, Borge L, Carrier A, Vasseur S, Bourgarel V, Buric D andré N, Braguer D and Carré M: AKT targeting as a strategy to boost chemotherapy efficacy in non-small cell lung cancer through metabolism suppression. Sci Rep 7: 45136, 2017.

Received May 2, 2017

Revised May 22, 2017

Accepted May 24, 2017 